\title{
The Effect of Jump to Box Exercises on Heading Ability
}

\author{
Ikhwanul Arifan ${ }^{1 *}$, Eri Barlian², and Afrizal. $\mathrm{S}^{3}$ \\ ${ }^{1,2,3}$ Dep. of Coaching, Faculty of Sport Science, Universitas Negeri Padang, Padang, Indonesia \\ *Corresponding author. Email: ikhwanularifan@fik.unp.ac.id
}

\begin{abstract}
This type of research is artificial experiments, this research aims to know the extent of the influence of exercise Jump To Box against the ability of the Heading, (Experimental Study on Soccer Club athlete The son of Pasaman). The population in this research is the son of The Club's soccer athletes Pasaman amounted to 43 people. This research sample taken from junior athletes as much as 20 people, the technique of taking sample by way of Porposive Sampling. The sample in this research is the junior athletes Football athletes is incorporated in the Football Club The son of Pasaman. The hypothesis presented in this study is an exercise Jump To Box give influence on the ability of the Headings on the Football Club's athletes The son of Pasaman.Data analysis uses the t-test, the results of the processing of data is 1$)$ based on table $t$ distribution with degrees of freedom $(\mathrm{dk}) \mathrm{n}-1(20-1=19)$ significant levels of 0.05 , then retrieved the table $t=2,093$. So $t$ count $i t=t$ table $>6,734>2,093$ then Ho in decline while the Ha is received. In conclusion, there is a significant influence of exercise Jump To Box against the ability of the Heading.
\end{abstract}

Keywords: Jump to Box, and Heading Ability

\section{INTRODUCTION}

Sport is a field that has developed rapidly in all levels of Indonesian society and also in other countries in the world, regardless of religion, age, country or political orientation. An individual who does sports continuously will maintain and even improve body performance, so that the person does not experience decreased performance which is certainly not expected by athletes and coaches (Haryanto \& Welis, 2019). Sports are no longer just a function of leading to a physically healthy life, but now sport has become a promising profession and can be a source of livelihood for an accomplished sportsman. Advances in science and technology lead to rapid changes in various orders of human life, resulting in globalization and free markets, Ridwan, M., \& Irawan, R. (2018). Therefore, to achieve and improve performance in sports, it is necessary to coach and develop sportsmen in a planned, tiered and sustainable manner by coaches, government, society and other organizations.

One of the sports that need to be fostered and increased in performance is the sport of football, because the sport of football is very popular with the community, this can be seen from the many football clubs that have emerged in the community. In almost every sub-district, district or city there is a football field and football matches are often held, such as matches between clubs, cities and districts. Each team definitely wants the best performance for its athletes. To achieve good performance in the sport of football requires coaching, facilities and infrastructure, persistence, strong will, mastery of techniques and tactics, strong mentality, and sufficient training and match experience. long and have a good physical condition or stamina, as stated by Syafruddin (2011: 16).

Sports activities have many supporting factors that affect achievement, such as: physical condition, technique, tactics, and mentality, Soniawan, V., \& Irawan, R. (2018). In addition to having good techniques, tactics, and mental sports, it also requires mastery of good physical conditions for athletes. According to Arwandi, J., \& Ardianda, E. (2018) in an effort to increase the achievement of football players. Exercise is one of the most determining factors in achievement. The form of exercise chosen will also be very decisive in achieving the desired training targets.

The best achievement or so-called peak achievement in sports coaching requires a planned preparation process that is gradual, directed, systematic and sustainable in other words that the preparation process includes the entire process starting from the preparation of training programs, implementation, programs in the field and up to evaluation of the 
exercise program in stages according to the goals to be achieved.

According to Syukur, A., \& Soniawan, V. (2015) football is a game that requires a lot of energy, intelligence on the field stimulates enthusiasm, while providing joy through togetherness in a team. In football, there are various basic techniques for playing football. Basic techniques are fundamental that must be mastered by all athletes in order to play football skillfully based on multilateral movement skills.

There are several techniques in the game of football, namely: (1) Kicking techniques, (2) techniques to hold and seize the ball, (3) technique to control the ball (Ball Controll), (4) technique of header (Heading). (5) technique of carrying the ball (dribbling), (6) technique of catching the ball (goal keeping). One of the dominant techniques used by athletes to attack and aim to score goals against the opponent's goal is the heading technique (Heading).

According to Fekum Ariesbowo (2010: 37) "passing theHeading is an important basic technique in football, a header is not just a way of ball with the head, but also as a mainstay for scoring goals against the opponent's goal." Therefore, the faster and more precise body movements. then the ball can increasingly be headed sharply into the goal and allows it to be difficult to anticipate by the opposing goalkeeper.

There are basic concepts that must be mastered in doing headings:

1. When you see the ball coming, move towards it to block its speed.

2. Pay attention to the direction the ball is coming from, and keep watching until the ball hits your forehead.

3. Do not close your eyes or you will be in pain, pay attention to the direction of movement of the ball that is coming and away from your body.

4. Head the ball with the top of your forehead, do not wear your temples or the top of your head.

5. Move your head back and firmly head the ball, don't just stand still and let the ball hit your head. Robert Koger (2007: 33).

According to Danny Mielke (2007: 49) Heading can provide a very big dimension in the game, players can Heading while jumping, jumping forward, dropping (diving), or staying still and pointing the ball sharply at the goal or a friend. team. According to Rozi (2010: 1) in the journal Sumartani Tamping, explains the basic technical skills in heading the ball (Heading) as follows:

1. Preparation Stage

a) Stand with your feet shoulder width apart or a stance, knees slightly low.

b) Both arms in front of the side of the body. c) The gaze is fixed on the ball.

2. Movement Stage

a) Flex the waist back and tighten the neck muscles and body weight resting on the hind legs.

b) The direction of view on the ball.

c) Move the waist forward, until the forehead is right in the direction of the ball.

d) To increase the speed or power of the ball, move your arms back.

3. End of Movement

a) Body movement brought forward.

b) Straighten knees and both heels lifted off the ground, the view follows the direction of the ball.

Joseph A. Luxbacher (2012: 103) also explains that when Heading try to contact the ball at the highest point of the jump, hold the curved body position until the very last moment, then push the body forward towards the ball, keeping the neck and head not moving.

In order to do Heading goodin the game of football, an athlete must have fast and precise movements and have a strong leg muscle explosive power. According to Bafirman (2008: 82) "Explosive Power is one of the important biomotor components in sports activities, because the explosive power will determine how hard people can hit, how far they throw, how high they jump, how fast they run and so on".

According to Arsil (2011: 71) said that "power is one of the important biomotor components in sports activities, because the explosive power will determine how hard a person can hit, how far to throw, how far to jump and how far to run". Arsil (2011: 73) also said that the explosive power is divided into two types: 1) the explosive power acyclic, 2) explosive Cyclic.

Arsil (2011: 74) reveals the explosive power is divided into two kinds:1) Power absolute mean power to overcome a the maximum external load, 2) power the relative means the power is used to overcome the burden of its own weight.

Bafirman (2008: 85) also explains the factors that affect power, among others:

1. Muscle strength

a. Maximum strength

b. Explosive power

c. Endurance strength

2. Speed of muscle contraction

Power refers to the explosive power of the leg muscles, which is the strength of the leg muscles in overcoming resistance or loads in a complete movement with a short speed. Irawadi (2001: 98) states that the factors that affect the explosive power of muscles are divided into:

a) Types of muscle fibers 
In the human body there are two types of muscle fibers, namely red muscle fibers and white muscle fibers. Red muscle fibers react more slowly (slow twitch fiber). This type is also known as slow twitch muscle. While white muscle fibers tend to react more quickly (fast twitch fiber), these muscles are often called fast twitch muscles.

b) The Muscle length

fibers also affects speed. Muscles that have longer fibers have a faster contraction power than muscles that have short fibers.

c) Muscle strength

In fact affect the speed of movement. Stronger muscles move or react faster than weak muscles.

d) Muscle shape

Muscles that run parallel to or parallel to the longitudinal axis have a higher contraction power than muscles that run diagonally to the longitudinal axis.

e) Muscle temperature

Temperature affects the level of muscle readiness. Muscles that are hot enough will act (contract) faster than muscles in cold temperatures.

f) Gender

Differences also affect speed. Men tend to be faster than women.

g) Fatigue

Muscle fatigue greatly affects muscle contraction, muscles that are in a tired state act slower than those that are fresh (not tired).

h) Intermuscular Coordination

Coordination or the interaction of several muscles during activities. In any physical activity that requires strength, it usually involves several muscle groups.

i) Intramuscular coordination

Where the strength (power output) also depends on the function of the nerves of the muscles involved in the performance of the task of the physical activity. The more muscle fibers in an activity, the greater the strength produced, and vice versa.

j) Muscle reactions to nerve stimulation

Muscle reactions to nerve stimulation of the muscles will react to exercise stimulation by 30 percent of the potential of the muscles concerned.

k) Joint angle

Some of the findings suggest that the maximum strength will be achieved when the joints involved during the activity are completely straight or close to that state.

According to Irawadi (2011: 96) "Muscle explosive power is a combination of several physical elements, namely the element of strength and the element of speed, meaning that the explosive power of muscles can be seen from the results of a performance performed using strength and speed." The higher the explosive power of a person's muscles. the higher the strength and speed elements, therefore the explosive power of the leg muscles in the sport of football is very important to be owned and improved by every football athlete.

The Panti Putra Club in Pasaman Regency is one of the football clubs in Pasaman Regency which consists of a team fostered by a coach named Desrizal, this club has participated in several matches between clubs in Pasaman Regency, and has even frequently participated in matches outside West Sumatra since 2000. Based on observations made on the Panti Putra club athletes in Pasaman Regency, it is known that in training and competition there are still many athletes who have a low level of leg muscle explosive power, which can be seen when athletes find it difficult to Heading when the athlete wants to score a goal against an opponent who has a goal. seen when it is difficult for athletes to Heading in front of the opponent's goal.

According to information from the Panti Putra club coach, Pasaman Regency, the ability of the leg muscle explosive power level is still low and weak, which shows that the athlete's movement is still slow when doing Heading, the ability Heading lowis due to the difficulty of athletes making fast and precise jumps. Thus it can be said that the ability of Heading Panti Putra athletes in Pasaman Regency is still low. The low ability is Heading caused by several factors, including: (1) form of training such as Jump To Box , (2) skipping , (3) squat jump (squat-jump), (4) squat thrust (squat-standing). In addition to the form of training, there are many things that affect the explosive power of the leg muscles such as: (1) lack of facilities and infrastructure, (2) nutrition, (3) discipline, (4) and less professional trainers in making training programs. Of the factors that cause the low capacity of Heading the club soccer athletePanti Putra Pasaman, the author chose one form of exercise that exercises Jump To Box (Jumping Into box).Because with this exercise, Jump To Box it will get very many uses to increase the power of leg muscles in doing Heading. Apart from being very useful, the exercise is Jump To Box also very simple and can be done anywhere.

Jump To Box is a form of exercise plyometric which aims to increase muscle explosiveness. Jump To Box has advantages, namely, increasing power leg muscle, increasing fitness and endurance, while the weaknesses, among others, are easily tiring and if not done carefully can cause injury. In the exercise Jump To Box, the height of the jumps carried out varies, according to the size of the box needed. When the foot 
rests on the box weight received by the leg muscles when landing will be greater.

According to Bafirman (2008: 89) Plyometrics is a training method for developing explosive abilities. Radclife (1985) explained that plyometrics exercises are very useful for the game of football when jumping to Heading,the goal of exercises plyometrics that help the athletes to be able to develop explosive power is needed in almost all sports. One form of training plyometric to increase the explosive power of the leg muscles is the exercise Jump To Box. Exercise Jump To Box is an exercise jump to top of the box beam then leaped back as the initial stance using both legs together. Donald A. Chu, (1992: 48).

In the journal mufidatul hasanah (2013: 27) Jump To Box is a special exercise to increase power leg muscle. The muscles developed in the exercise Jump To Box include thigh flexion, knee extension, adduction and abduction. The description of the movement Jump To Box is as follows:

Prefix : Stand with your feet hip-width apart Implementation :

1. Body position facing the box.

2. Squat a little and jump straight from the ground to the box.

3. Use double swing arms

4. Feet lands on ground spontaneously

5. And repeat

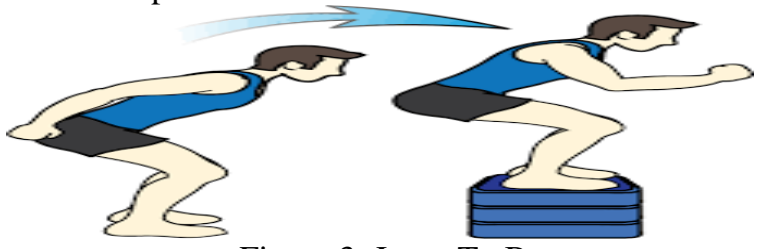

Figure 3. Jump To Box

1. Advantages of the exercise plyometric jump to box

a. The muscles in the legs contract more quickly.

b. Easy to do and simple movements.

c. Can be done anywhere both indoors and outdoors.

2. Weaknesses of Jump To Box

a. Fatigue faster because at the time of jumping into the box the surface is higher than the surface at the initial repulsion.

b. The movement is getting slower and slower.

c. Stamina is drained faster. Donald A. Chu, (1992: 28) in the journal (Mufidatul Hasanah, 2013: 27)

\section{RESEARCH METHOD}

This research is experimental. Judging from the research location, this research is a quasi-experimental research type. The independent variable is the exercise jump To Box and the dependent variable is the ability of Heading the soccer athletes at the Putra Panti club, Pasaman Barat.
This study consisted of a sample group that would perform the same form of training (treatment). Before doing the exercise, the initial test (carried out pretest) is, then for 16 meetings the group is given treatment (practice), after that a final test (is carried out posttest). Therefore, the research design is: pre-test and post-test one group design.

The population of this research is the whole object to be studied. This is in accordance with the opinion stated by Putrawan (1990: 5-7), namely "Population is all data that concerns us within a specified scope and time." The population in this study were 43 athletes of the Panti Putra football club.

This research was started on 19 February 2015 which was carried out in the Maninjau Kabupaten of Pasaman Barat.

The sample of this study was taken from a population of 20 junior athletes. In this study, the sampling was carried out using the "technique Purposive sample". Purposive sampling is a sampling technique in accordance with the required sample requirements, the researcher determines the sample himself taken for certain considerations, so the sample is not taken randomly, but is determined by the researcher himself.

Table 1. Population of Athletes Club Panti Putra Pasaman

\begin{tabular}{|c|c|}
\hline Senior & 23 \\
\hline Junior & 20 \\
\hline
\end{tabular}

Based on the sampling technique, the researchers took the sample in this study 20 junior athletes who are soccer athletes who are members of the Panti Putra football club. The test that is conducted is the Heading Test.

This research can be processed using descriptive and statistics inferential, to analyze the experimental results using the pre-test and post-test one group design with the Arikunto formula (2010: 309):

$$
\mathrm{t}=\frac{\mathrm{Md}}{\sqrt{\frac{\sum \mathrm{X}^{2} \mathrm{~d}}{\mathrm{~N}(\mathrm{~N}-1)}}}
$$

Note:

Md = mean of difference between pre test and post test

$\mathrm{Xd}=$ deviation of each subject

$\sum \mathrm{X}^{2} \mathrm{~d}=$ sum of squares of deviation

$\mathrm{N} \quad=$ subjects in the sample

d.b. $\quad=$ determined by $\mathrm{N}-1$ 


\section{RESULTS AND DISCUSSION}

The normality test was carried out with the Lilliefors test with a significant level of 0.05 with the results of the following requirements: The normality test was carried out with the Lilliefors test, the results of the normality test on the research variables were the results of ability Heading (pretest and posttest).

Table 2. Data Normality Test for Pretest and Posttest

\begin{tabular}{|c|c|c|}
\hline Variable & $\mathrm{L}_{\text {count }}$ & $\mathrm{L}_{\text {Table of }}$ \\
\hline Pretest Data & 0,827 & 0,190 \\
\hline Posttest Data & 0,516 & 0,190 \\
\hline
\end{tabular}

From the table above, it can be seen that the pretest data after the calculation results in $\mathrm{L}_{\text {count }}$ of 0.827 and $\mathrm{L}_{\text {table }}$ of 0.190 . This means that $\mathrm{L}_{\text {count }}$ is greater than $\mathrm{L}_{\text {table. }}$ It can be concluded that the distribution of pretest data is normally distributed. For data testing the posttest results produce $\mathrm{L}_{\text {count }}$ of 0.516 and $\mathrm{L}_{\text {table }}$ is 0.190 . This means that $\mathrm{L}_{\text {count }}$ is greater than $\mathrm{L}_{\text {table. The hypotheses }}$ tested in this study are:

Ho : There is no significant effect between training Jump to Box (X)on the results of Ability Heading (Y) at the Panti Putra Club Athlete, Pasaman Barat.

H1 : There is a significant influence between training Jump to box (X)on the results of Ability Heading (Y) in the Athlete Club at Panti Putra Pasaman Barat.

The data obtained were analyzed descriptively, then the research hypothesis was tested according to the problem, namely: "there is a significant effect of training Jump to Box with the results of the ability heading (Y). Based on the T-test analysis, it produces $t_{\text {count }}$ of 6,734 and $t_{\text {table }}$ of 2,093. Means $t_{\text {count }}>t_{\text {table. }}$. It can be concluded that $\mathrm{HO}$ is rejected and $\mathrm{Ha}$ is accepted.

It can be concluded that there is a significant effect between training Jump to Box (X) with the results of Ability Heading (Y) in the Athletes Club at the Panti Putra Pasaman Barat at the alpha level of 0.05 with a confidence level of $95 \%$.

\section{CONCLUSION}

Based on the findings and data processing carried out, it can be concluded that based on the $\mathrm{t}$ distribution table with degrees of freedom (dk) n-1 = $20-1=19$ with a significant level of 0.05 , it is obtained $\mathrm{t}_{\text {table }}=2.093$. So $\mathrm{t}_{\text {count }}>\mathrm{t}_{\text {table }}=6,734>2,093$ then Ho is rejected while $\mathrm{Ha}$ is accepted. In conclusion, there is a significant effect of the exercise Jump to box on ability heading.

\section{REFERENCES}

[1] Ariesbowo Fekum. (2010). Menjadi pemain sepakbola yang tangguh. Jakarta: Be Champion.

[2] Arsil. (2011). Pembinaan Kondisi Fisik. Padang: Sukabina

[3] Arwandi, J., \& Ardianda, E. (2018).Latihan Zig-Zag Run Dan Latihan Shuttle Run Berpengaruh Terhadap Kemampuan Dribbling Sepakbola. Performa, 3(01), 32-32.

[4] Bafirman. (2008). pembentukan kondisi fisik. Padang: UNP

[5] Donald A. Chu, (1992:48) "pengaruh latihan pliometrik depth jump dan jump to box terhadap power otot tungkai pada atlet bolavoli klub tugu muda kota semarang”. pada jurnal Mufidatul Hasanah (2013)

[6] Haryanto, J., \& Welis, W. (2019). Exercising Interest in the Middle Age Group. Performa Olahraga, 4(2), 214-223. https://doi.org/https://doi.org/10.24036/kepel.v4i02 .131

[7] Irawadi, Hendri. (2011). Kondisi Fisik Dan Pengukurannya. FIK. UNP: Padang.

[8] Koger Robert. (2007). Latihan Dasar Andal Sepak Bola Remaja, Latihan dan Ketermpilan Andal Untuk Pertandingan Dasar Yang Lebih Baik.Klaten: Saka Mitra Kompetensi.

[9] Luxbacher A Joseph. (2012). Sepak Bola. Jakarta: Rajawali Pers.

[10] Menpora. (2007). Undang-Undang RI Nomor 3 Tahun 2005. Tentang Sistem Keolahragaan Nasional. Bandung: Citra Umbara

[11] Mielke Danny. (2007). Dasar Dasar Sepakbola. Bandung: Human Kinetics.

[12] Umar. (2007). Fisiologi Olahraga.FIK. UNP Padang

[13] Ridwan, M., \& Irawan, R. (2018). Validitas Dan Reliabilitas Tes Kondisi Fisik Atlet Sekolah Sepakbola (Ssb) Kota Padang "Battery Test Of Physical Conditioning". Performa Olahraga, 3(02), 90-90.

[14] Rozi. (2010) "Meningkatkan Ketrampilan Heading Permainan Sepak BolaMelalui Latihan LompatLompat di Tempat Siswa Kelas V SDN Inpres Cemerlang” pada jurnal Sumartani Tamping.

[15] Soniawan, V., \& Irawan, R. (2018).Metode Bermain Berpengaruh Terhadap Kemampuan Long Passing Sepakbola. Performa Olahraga, 3(01), 42-42.

[16] Syafruddin.(2011). ilmu kepelatihan olahraga.teori dan aplikasi dalam pembinaan olahraga. Padang: UNP PREES

[17] Syukur, A., \& Soniawan, V. (2015). The Effects Of Training Methods And Achievement Motivation 
Toward Of Football Passing Skills. JIPES-Journal Of Indonesian Physical Education And Sport, 1(2), 73-84.

[15] Zalfendi. (2010) Buku Ajar Sepak Bola. Padang: Sukabina. 